\title{
Psychosocial Problems in Adolescents with Sickle Cell Anaemia on Hydroxyurea in Jos, North Central Nigeria
}

\author{
Daniel O. Aina ${ }^{1 *}$, Ishaya I. Abok ${ }^{2}$, Akinyemi O. D. Ofakunrin ${ }^{2}$, Tolulope O. Afolaranmi ${ }^{3}$, Olumide A. Ajayi ${ }^{4}$, Lucius C. \\ Imoh $^{1}$, Ayuba Affi ${ }^{1}$, Olumide Olaniru ${ }^{1}$, Bawa Abubakar ${ }^{5}$, Christian O. Isichei ${ }^{1}$, Edache S. Okpe ${ }^{2}$ \\ ${ }^{1}$ Department of Chemical Pathology, Jos University Teaching Hospital, Jos Nigeria \\ ${ }^{2}$ Department of Paediatrics, Jos University Teaching Hospital, Jos, Nigeria \\ ${ }^{3}$ Department of Community Medicine, Jos University Teaching Hospital, Jos, Nigeria \\ ${ }^{4}$ Department of Sociology, Skyline University Kano, Nigeria \\ ${ }^{5}$ Department of Chemical Pathology, Abubakar Tafawa Balewa University, Bauchi, Nigeria
}

\begin{abstract}
Article History
Received: 15.12 .2021

Accepted: 26.01.2022

Published: 31.01 .2022

Journal homepage: https://www.easpublisher.com

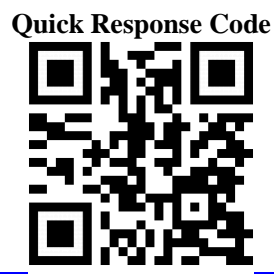

Abstract: Background: A lot of adolescents with sickle cell anaemia constantly face unpleasant ill health conditions such as chronic pain as well as feelings of frustration over their general well-being and psychological adjustment which may distort medical care and spell bad prognosis for their condition. This study therefore assessed the psychosocial problems of adolescents with sickle cell anaemia who are on hydroxyurea in Jos, North central Nigeria. Method: This study was a comparative cross-sectional study among adolescents with Sickle Cell Anaemia (SCA) who were on hydroxyurea and those not on hydroxyurea in Jos University Teaching Hospital, Jos, North Central Nigeria. Eighty-eight participants who were from ages of 11- 17 years were selected for the study between February and August, 2020. Data were collected with the use of questionnaire. Data analysis was conducted using Statistical Package for Social Sciences version 18 (SPSS Inc., Chicago, IL, USA). Test for association was done using Fisher's exact test. Results: The result of the study showed that there was no difference between those on hydroxyurea and those not on hydroxyurea. The study equally showed that there was no statistically significant difference $(p>0.05)$ in psychosocial life of adolescent SCA patients who used hydroxyurea and those who did not use hydroxyurea. Conclusion: Hydroxyurea medication in adolescents with sickle cell anaemia for a year and above did not impact on their psychosocial life.

Keywords: Psychosocial problem, Adolescents, Sickle cell anaemia, Incapacitating, Hyperactivity.

Copyright (C) 2022 The Author(s): This is an open-access article distributed under the terms of the Creative Commons Attribution 4.0 International License (CC BY-NC 4.0) which permits unrestricted use, distribution, and reproduction in any medium for non-commercial use provided the original author and source are credited.
\end{abstract}

\section{INTRODUCTION}

Sickle cell anaemia (SCA) is a chronic and progressively incapacitating condition that is characterized by ongoing hemolytic anaemia, repeated acute painful vaso-occlusive events, organs dysfunction and early death if not treated early $[1,3]$. The disorder occurs as a result of inheritance of two $\mathrm{HbS}$ by an individual from both parents. Globally, SCA is present in over $5 \%$ of the world's population and seen annually in over 300,000 newborns out of which, Nigeria; the most populated sub-Saharan country has about $50 \%$ of this birth in a year with an increasing prevalence of SCA complications seen with increasing age $[3,4]$.
Adolescence is a transitory stage between childhood and adulthood, from 10-19 years characterized by rapid physical growth, accompany with changes in body shape and composition as well as neurological and cognitive changes $[5,6]$. The adolescents with sickle cell anaemia constantly experience unpleasant health conditions such as chronic pain; feelings of frustration over their general wellbeing and psychological adjustment which may distort medical care and spell bad prognosis for the condition [6-8].

However, with the advancement in health care services such as availability of pneumococcal vaccinations, penicillin prophylaxis, trans-cranial

*Corresponding Author: Daniel O. Aina

Department of Chemical Pathology, Jos University Teaching Hospital, Jos Nigeria 
ultrasound (TCD) screening for stroke preventions, safe transfusions for acute and chronic complications and importantly the use of hydroxyurea; a cytosine arabinoside that raises the number of fetal hemoglobin and subsequently reduces chronic pain and improve quality of life of SCA patients. This has now made it possible for many children with SCA to survive into adolescent stage and beyond [9-12].

This good development is, however, associated with other barrage of problems that accompany adolescence and as well as psychological maladjustment seen in chronic ill-health conditions like peer problems, emotional problems, conduct and hyperactivity which may negatively impact the affected individuals, the siblings, families and society at large if not recognized and appropriately handled [14, 15]. Hence, an holistic approach must be employed in order to detect and treat the illness-related; social, academic, familial issues as well as psychological problems associated with SCA in adolescents [16-19]. This will help to provide an effective and efficient care for this category of patients. Therefore, this study assessed the psychosocial problems of adolescents with sickle cell anaemia and impact of hydroxyurea on the problems in Jos, North central Nigeria.

\section{Materials ANd Methods Study area}

The study was conducted at the departments of Chemical Pathology and Paediatric-hematologyoncology of Jos University Teaching Hospital, Jos, Nigeria. The teaching hospital is 600 bed tertiary facility in Jos metropolis, North central region of Nigeria. The Hospital is situated at Lamingo, Jos North local Government area of Plateau State. It serves as a referral centre for neighboring states like Bauchi, Nassarawa, Benue, Adamawa, Taraba, Kogi, Southern Kaduna in Kaduna State and Gombe.

\section{Study Population}

This study recruited adolescents with SCA between the ages of 11-17 years who were confirmed earlier with cellulose acetate electrophoresis

\section{Study Design}

This was a comparative cross-sectional study to determine the psychosocial problems in adolescents with SCA and impact of hydroxyurea on the problems. The study was grouped into two; (1) those taking hydroxyurea for at least six months prior to the collection of the data and (2) those yet to commence hydroxyurea as at the time of collecting data.

\section{Study technique and sample size determination}

Following recruitment of children with SCA who met the inclusion criteria, a computer-generated table of random number was used to select the study participants from eligible patients. The sample size was initially calculated from the infinite population, using an appropriate formula which gave minimum sample size of 86 . Then, a sample size of 88 was taken after applying an attrition factor of $2 \%$ in order to allow for late withdrawal of assents and consents. Socioeconomic status was according to Olusanya et al., classification [20].

\section{Inclusion criteria}

i. $\quad$ Sickle cell anaemic adolescents between 11 and 17 years bracket who were in a steady state (no crisis, fever and infection in preceding 1 month and no blood transfusion in the past 3 months) [10].

ii. Patients who consented to participate in the study.

\section{Exclusion criterion}

i. Children with malignancy, HIV that could aggravate psychosocial issues were excluded [11].

\section{Ethical Clearance}

This study was done after the approval of Ethics committee at Jos University Teaching Hospital, Jos. Thereafter, parental consent and children's assent respectively were taken for children between 11-14 years while children between ages 15-17years gave their informed consents.

\section{Data Collection}

The adolescents were then given a strength and difficulties questionnaires that have 25 items grouped into 5 scales for the items. The scores were grouped into (1) Emotional scales (2) Conduct problems scale (3) Hyperactivity/inattention scale (4) Peer pressure scale (5) Pro-social scales. For each of the 5 scale, the scores range from $0-10$ if all items were completed [15, $21,22]$. The Internalizing score (emotional problem score + peer problem score) and Externalizing score (conduct score + hyperactivity score) were considered for the psychosocial problems of adolescents who were on $\mathrm{HU}$ for at least 6 months and for those not on $\mathrm{HU}$ $[21,22]$.

Scoring of strength and difficulties questionnaire for age 11-17 years entails:

1. Scoring each of the five scales according to what is set out in the tables 1A-E below (total range for each is $0-10$ )

2. Calculate the internalizing and externalizing scores 
Table 1A: shows conduct problems that indicates anger, obedience, fight, cheating and act of stealing in the participants

\begin{tabular}{|c|c|c|c|c|c|}
\hline \multicolumn{6}{|c|}{ Conduct Problems Scale } \\
\hline & & $\begin{array}{l}\text { Not } \\
\text { True }\end{array}$ & $\begin{array}{l}\text { Somewhat } \\
\text { True }\end{array}$ & $\begin{array}{l}\text { Certainly } \\
\text { True }\end{array}$ & SCORE \\
\hline ITEM 5: & Often has temper tantrums or hot tempers( I get very angry) & 0 & 1 & 2 & \\
\hline ITEM 7: & Generally obedient....( I usually do as am told) & 2 & 1 & 0 & \\
\hline ITEM 12: & Often fights with other children (I fight a lot) & 0 & 1 & 2 & \\
\hline ITEM 18: & & 0 & 1 & 2 & \\
\hline ITEM 22 & & 0 & 1 & 2 & \\
\hline
\end{tabular}

Table 1B: Hyper-activity score indicates complains of restlessness, fidgeting, distraction, thinking things out and see tasks through to the end

\begin{tabular}{|l|l|l|l|l|}
\hline & Not True & Somewhat True & Certainly True & SCORE \\
\hline ITEM 2: & 0 & 1 & 2 & \\
\hline ITEM 10: & 0 & 1 & 2 & \\
\hline ITEM 15: & 0 & 1 & 2 & \\
\hline ITEM 21: & 2 & 1 & 0 & \\
\hline ITEM 25 & 2 & 1 & 0 & \\
\hline \multicolumn{5}{|l|}{ Total Hyperactivity Scale score: } \\
\hline
\end{tabular}

Table 1C: indicates complains of headaches, worries, being unhappy, being nervous and fearful

\begin{tabular}{|l|l|l|l|l|l|}
\hline Emotional problems scale & \multicolumn{2}{|l|}{} \\
\hline & \multicolumn{2}{|l|}{$\begin{array}{l}\text { Not } \\
\text { True }\end{array}$} & $\begin{array}{l}\text { Somewhat } \\
\text { True }\end{array}$ & $\begin{array}{l}\text { Certainly } \\
\text { True }\end{array}$ & SCORE \\
\hline ITEM 3: & $\begin{array}{l}\text { Often complains of headaches.. (I get a lot of } \\
\text { headaches) }\end{array}$ & 0 & 1 & 2 & \\
\hline ITEM 8: & Many worries...(I worry a lot) & 0 & 1 & 2 & \\
\hline ITEM 13: & $\begin{array}{l}\text { Often unhappy, down-hearted (I am often } \\
\text { unhappy..) }\end{array}$ & 0 & 1 & 2 & 2 \\
\hline ITEM 16: & $\begin{array}{l}\text { Nervous or clingy in new situations..(I am nervous } \\
\text { in new situations...) }\end{array}$ & 0 & 1 & 2 & \\
\hline ITEM 24: & Many fears, easily scared (I have many fears...) & 0 & 1 & & \\
\hline TOTAL Emotional Problems Scale Score: & & & \\
\hline
\end{tabular}

Table 1D: indicates solitude, having a friend, liked by other children, bullied by other children

\begin{tabular}{|c|c|c|c|c|}
\hline \multicolumn{5}{|c|}{ Peer problems scale } \\
\hline & Not True & Somewhat True & Certainly True & SCORE \\
\hline ITEM 6: & 0 & 1 & 2 & \\
\hline ITEM 11: & 2 & 1 & 0 & \\
\hline ITEM 14: & 2 & 1 & 0 & \\
\hline ITEM 19: & 0 & 1 & 2 & \\
\hline ITEM 23: & 0 & 1 & 2 & \\
\hline \multicolumn{4}{|c|}{ L Peer problems scale: } & \\
\hline
\end{tabular}

Table 1E: shows consideration of other's feelings, sharing with other children,helpful if someone is hurt and kind to younger children

\begin{tabular}{|l|l|l|l|l|l|}
\hline Pro-social Score & $\begin{array}{l}\text { Not } \\
\text { True }\end{array}$ & $\begin{array}{l}\text { Somewhat } \\
\text { True }\end{array}$ & $\begin{array}{l}\text { Certainly } \\
\text { True }\end{array}$ & SCORE \\
\hline ITEM 1: & $\begin{array}{l}\text { Considerate of other people's feelings( I try to be nice to other } \\
\text { people) }\end{array}$ & 0 & 1 & 2 \\
\hline ITEM 4: & Shares readily with other children..(I usually share with others) & 0 & 1 & 2 & \\
\hline ITEM 9: & Helpful if someone is hurt (I am helpful if someone is hurt..) & 0 & 1 & 2 & \\
\hline ITEM 17: & Kind to younger children(I am kind to younger children) & 0 & 1 & 2 & \\
\hline ITEM 20: & Often volunteers to help others...(I often volunteer to help others) & 0 & 1 & 2 & \\
\hline Total conduct problems scale score: & & & \\
\hline
\end{tabular}


Table 1F

\begin{tabular}{|l|l|l|l|}
\hline & Low need & Some need & High need \\
\hline Emotional symptoms score & $0-4$ & 5 & $7-10$ \\
\hline Conduct problems score & $0-2$ & 3 & $4-10$ \\
\hline Hyperactivity score & $0-5$ & 6 & $7-10$ \\
\hline Peer problem score & $0-3$ & 3 & $4-10$ \\
\hline Pro-social behaviour problem & $6-10$ & 5 & $0-4$ \\
\hline Total difficulties score & $0-15$ & $16-19$ & $20-40$ \\
\hline
\end{tabular}

The above table $\mathrm{F}$ explains three categories of need in the adolescents with SCA. Low need indicates normal psychosocial status; some need shows raised value however still normal while high need is elevated values and calls for concerns.

\section{RESULT}

Socio-demographic characteristics of the study participants

Eighty-eight adolescents participated in the study among whom were 41(46.6\%) females and
$47(53.4 \%)$ males. With respect to ethnicity, adolescents who are indigenes of Plateau State accounted for 35 $(39.8 \%)$ of the participants, Hausa 31(35.2\%), Igbo 8 $(9.1 \%)$, Yoruba $7(7.9 \%)$ and other ethnic groups 5 $(5.7 \%)$. Most of the study participants, $59(67 \%)$ had secondary level of education while $6(6.8 \%)$ had tertiary education .Thirty nine $(44.3 \%)$ were in low socioeconomic class; fifteen $(17.0 \%)$ were in middle socioeconomic class while $34(38.6 \%)$ were in high socioeconomic class as seen in Table 1 below.

Table 1: Demographic characteristics of participants $(n=88)$

\begin{tabular}{|l|l|l|}
\hline Variable & Frequency (f) & Percentage (\%) \\
\hline Sex & & \\
Female & 41 & 46.6 \\
Male & 47 & 53.4 \\
\hline Ethnic Affiliation & 35 & \\
Plateau ethnic group & 7 & 39.8 \\
Yoruba & 31 & 7.9 \\
Hausa & 2 & 35.2 \\
Fulani & 8 & 2.3 \\
Igbo & 5 & 9.1 \\
Others & 88 & 5.7 \\
Total & & 100.0 \\
\hline Child's Education & 23 & \\
Primary education & 59 & 26.1 \\
Secondary education & 6 & 67.0 \\
Tertiary institution & 88 & 6.8 \\
Total & & 100 \\
\hline Socio-Economic Score & 39 & \\
\hline Low Socio-economic class (4-5) & 15 & 17.0 \\
\hline Middle Socio-economic class (3) & 15.3 \\
\hline High Socio-economic class (1-2) & 34 & 38.6 \\
\hline Total & 88 & 100.0 \\
\hline
\end{tabular}

Table 2 indicated the psychosocial life of participants enrolled for the study. For emotional score, conduct problem score, hyperactivity score, peer problem score and pro-social score; low need values were $87.5 \%, 88.6 \%, 94.3 \%, 76.1 \%$ and $84.1 \%$ respectively while some need was $4.5 \%, 4.5 \%, 3.4 \%$, $13.6 \%$ and $4.5 \%$ in emotional score, conduct problem score, hyperactivity score, peer problem score and prosocial score respectively. High need values were $8.0 \%$, $6.8 \%, 2.3 \%, 10.2 \%$ and $11.4 \%$ for emotional score, conduct problem score, hyperactivity score, peer problem score and pro-social score respectively. Total difficulties score for low need, some need and high need were $86.4 \%, 6.4 \%$ and $6.4 \%$ consecutively. 
Table 2: Psychosocial life of the study participants $(n=88)$

\begin{tabular}{|l|l|l|}
\hline Variable & $\mathbf{f}$ & $\mathbf{\%}$ \\
\hline Emotional Score & & \\
\hline High need (7-10) & 7 & 8.0 \\
\hline Low need (0-5) & 77 & 87.5 \\
\hline Some need (6) & 4 & 4.5 \\
\hline Conduct Problem Score & & \\
\hline High need (5-10) & 6 & 6.8 \\
\hline Low need (0-3) & 78 & 88.6 \\
\hline Some need (4) & 4 & 4.5 \\
\hline Hyperactivity Score & & \\
\hline High need (7-10) & 2 & 2.3 \\
\hline Low need (0-5) & 83 & 94.3 \\
\hline Some need (6) & 3 & 3.4 \\
\hline Peer Problem Score & & \\
\hline High need (6-10) & 9 & 10.2 \\
\hline Low need (0-3) & 67 & 76.1 \\
\hline Some need (4-5) & 12 & 13.6 \\
\hline Total Score & & \\
\hline High need (20-40) & 6 & 6.8 \\
\hline Low need (0-15) & 76 & 86.4 \\
\hline Some need (16-19) & 6 & 6.8 \\
\hline Pro-social Score & & \\
\hline High need (0-4) & 10 & 11.4 \\
\hline Low need (6-10) & 74 & 84.1 \\
\hline Some need (5) & 4 & 4.5 \\
\hline
\end{tabular}

Figure 1 shows hydroxyurea use in $57(64.8 \%)$ of the study population while $31(35.2 \%)$ were not on hydroxyurea during the course of the study.

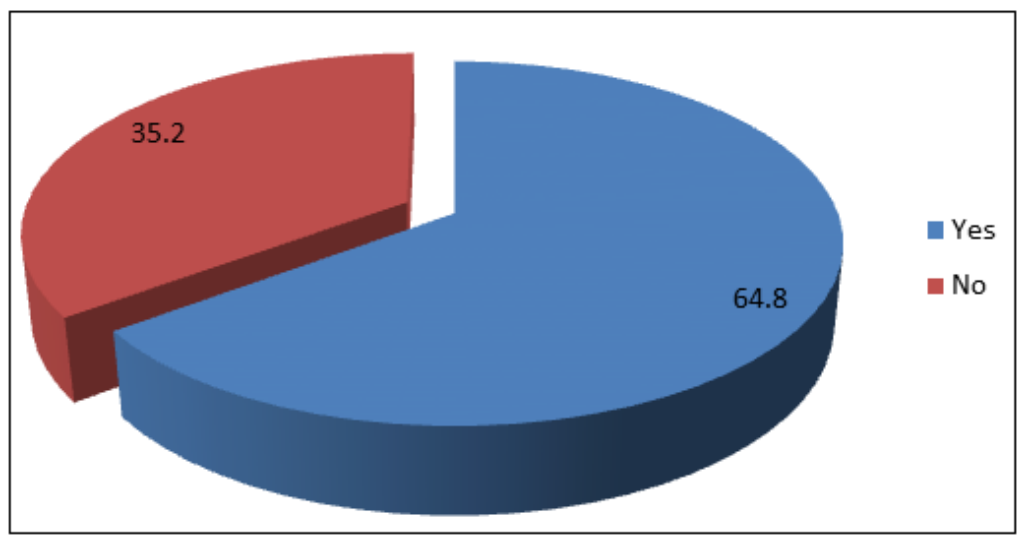

Figure 1: Use of hydroxyurea among the study participants $(n=88)$

Table 3 below indicated relationship between participants on hydroxyurea and those not on hydroxyure.
Fifty seven adolescents $(64.8 \%)$ were on hydroxyurea while thirty one $(35.2 \%)$ were not on hydroxyurea in this study. There was no statistically significant difference between those on hydroxyurea and those not on hydroxyurea $(\mathrm{p}=0.519)$.

Table 3: Relationship between participants on HU and those not on HU use (n = 88)

\begin{tabular}{|l|l|l|l|l|l|}
\hline \multicolumn{4}{|l|}{ Gender } & \multirow{2}{*}{ Chi-square } & p-value \\
\cline { 1 - 4 } HU use & Male & Female & Total & & \\
\hline Yes & $29(50.9)$ & $28(49.1)$ & $57(100.0)$ & 0.417 & 0.519 \\
\hline No & $18(58.1)$ & $13(41.9)$ & $31(100.0)$ & & \\
\hline
\end{tabular}


Hydroxyurea use and psychosocial needs among participants were stated (in Table 4) below. In all the scales (emotional, conduct, hyperactivity, peer problem and pro-social), the number of those on $\mathrm{HU}$ were more than those not on hydroxyurea. However, there was no statistically significant difference between those on hydroxyurea and those not on hydroxyurea.

Table 4: Significant differences between use of HU and psychosocial needs of participants
\begin{tabular}{|l|l|l|l|l|l|}
\hline \multicolumn{7}{|l|}{ HU use } & Chi-square & p-value \\
\hline Emotional Score & Yes f (\%) & No f $(\%)$ & Total f $(\%)$ & & \\
\hline Low need (0-5) & $50(87.7)$ & $27(87.1)$ & $77(87.5)$ & 0.701 & 0.807 \\
\hline Some need (6) & $2(3.5)$ & $2(6.5)$ & $4(4.5)$ & & \\
\hline High need (7-10) & $5(8.8)$ & $2(6.5)$ & $7(8.0)$ & & \\
\hline Conduct Score & & & & & \\
\hline Low need (0-3) & $50(87.7)$ & $28(90.3)$ & $78(88.6)$ & 0.277 & 0.999 \\
\hline Some need (4) & $3(5.3)$ & $1(3.2)$ & $4(4.5)$ & & \\
\hline High need (5-10) & $4(7.0)$ & $2(6.5)$ & $6(6.8)$ & & \\
\hline Hyperactivity Score & & & & & 0.999 \\
\hline Low need (0-5) & $54(94.7)$ & $29(93.5)$ & $83(94.3)$ & 0.683 & \\
\hline Some need (6) & $2(3.5)$ & $1(3.2)$ & $3(3.4)$ & & \\
\hline High need (7-10) & $1(1.8)$ & $1(3.2)$ & $2(2.3)$ & & \\
\hline Peer Problem Score & & & & & \\
\hline Low need (0-3) & $43(75.4)$ & $24(77.4)$ & $67(76.1)$ & 0.113 & \\
\hline Some need (4-5) & $8(14.0)$ & $4(12.9)$ & $12(13.6)$ & & \\
\hline High need (6-10) & $6(10.5)$ & $3(9.7)$ & $9(10.2)$ & & \\
\hline Total Score & & & & & \\
\hline Low need (0-15) & $50(87.7)$ & $26(83.9)$ & $76(86.4)$ & 0.824 & 0.920 \\
\hline Some need (16-19) & $4(7.0)$ & $2(6.5)$ & $6(6.8)$ & & \\
\hline High need (20-40) & $3(5.3)$ & $3(9.7)$ & $6(6.8)$ & & \\
\hline Pro-social Score & & & & & \\
\hline Low need (6-10) & $48(84.2)$ & $26(83.9)$ & $74(84.1)$ & 0.375 & \\
\hline Some need (5) & $3(5.3)$ & $1(3.2)$ & $4(4.5)$ & & \\
\hline High need (0-4) & $6(10.5)$ & $4(12.9)$ & $10(11.4)$ & & \\
\hline
\end{tabular}

\section{DISCUSSION}

Sickle cell anaemia has no impact on psychosocial status of the adolescents whether the ones on hydroxyurea and those not taking hydroxyurea as seen in this study. This is contrary to another study which explained that boys who were not on hydroxyurea had more psychosocial problems than girls [23]. This difference could be harped on the fact that former was hospital-based study while the later was community-based. Also, population of the adolescents involved in our study was below 100, as against over 400 participants involved in the study.

Again, our study got reports directly from the adolescents and not from the parents. This could be the reason while no impact of sickle cell anaemia was seen in the psychosocial life of the adolescents enrolled for this study. Earlier study corroborated the report which stated that there was stability in psychosocial life of adolescents reported by themselves but otherwise if reported by parents $[24,2]$.

Despite more males were taking hydroxyurea as compared to females. There was no difference in psychosocial life of male participants when compared to females. The socioeconomic status as determined by Olusanya et al., was average and above [20]. This may be connected with the earlier study that indicated that even though SCD is associated with many psychosocial malfunctions, other factors could also support the pattern of life of patients more than socio-economic status; for instance family support, coping responses and improved healthcare services at their disposals [25].

Patient-based reports and data collection in this study might have impacted more than psychosocial needs of adolescents on hydroxyurea which was not different from the ones not on hydroxyurea.

\section{LIMITATION}

The type of questions used in this study are closed questions type which do not allow participants to explain their answers in clear terms. This might have introduced bias while interpreting due to categories of questions raised. Again, more information on the socioeconomic status would have been more resourceful. Also, opportunistic selection of patients in a clinic setting as it was done in this study might have given different outcome if it is community-based method.

\section{Conclusion}

The psychosocial needs of participants in this study was not influenced by hydroxyurea use. This 
might be due to several factors that dictate the psychosocial life of patients with SCD like socioeconomic status, education level of the patient/caregivers, coping strategies and general standard of life. It then shows in the study that hydroxyurea did not impact the psychosocial life of the adolescents. However, future studies in this area may shed more light on the implications of psychosocial life and aforementioned factors.

\section{Acknowledgements}

I appreciate Queen Bello and Selyn Copse for assisting in data collation and analysis.

\section{Competing Interest}

The authors declare that they have no competing interest.

\section{Author's Contributions}

DOA conceptualized, wrote the manuscript and study protocol, collected data and analysed, IA conceptualized the study and every other author reviewed and approved the manuscripts

\section{REFERENCES}

1. McGann, P. T. (2016). Time to invest in sickle cell anemia as a global health priority. Pediatrics, 137(6), 1-6. https://pediatrics.aappublications.org/content/137/6 /e20160348

2. Anie, K. A., Egunjobi, F. E., \& Akinyanju, O. O. (2010). Psychosocial impact of sickle cell disorder: perspectives from a Nigerian setting. Globalization and health, 6(1), 1-6.

3. Sani, M. A., Adewuyi, J. O., Babatunde, A. S., Olawumi, H. O., \& Shittu, R. O. (2015). The iron status of sickle cell anaemia patients in ilorin, north central nigeria. Advances in hematology, 2015.

4. Galadanci, N., Wudil, B. J., Balogun, T. M., Ogunrinde, G. O., Akinsulie, A., Hasan-Hanga, F., ... \& Adekile, A. D. (2014). Current sickle cell disease management practices in Nigeria. International health, 6(1), 23-28.

5. Miranda, V. P. N., Faria, F. R. D., Faria, E. R. D., \& Priore, S. E. (2014). Somatic maturation and body composition in female healthy adolescents with or without adjustment for body fat. Revista Paulista de Pediatria, 32, 78-84.

6. Onukwuli, V. O., Ikefuna, A. N., Nwokocha, A. R., Emodi, I. J., \& Eke, C. B. (2017). Relationship between zinc levels and anthropometric indices among school-aged female children with sickle cell anemia in Enugu, Nigeria. Nigerian journal of clinical practice, 20(11), 1461-1467.

7. Stacy, A. M., \& Joan, J. (1986). Psychological and social concomitants of Sickle Cell Anaemia in Adolescent. Journal of Paed Psychology, 11(3), 112.
8. Muchaud, P. A., Viner, R., \& Suris, J. C. (2004). Adolescents with a chronic disease: developmental, 84, 938-942.

9. Morgan, S. A., \& Jackson, J. (1986). Psychological and social concomitants of sickle cell anemia in adolescents. Journal of Pediatric Psychology, 11(3), 429-440.

10. Emechebe, G. O., Onyire, N. B., Orji, M. L., \& Achigbu, K. I. (2017). Sickle cell disease in Nigeria: A review. IOSR Journal of Dental and Medical Sciences, 16(1), 87-94.

11. McGann, P. T., \& Ware, R. E. (2011). Hydroxyurea for sickle cell anemia: what have we learned and what questions still remain?. Current opinion in hematology, 18(3), 158-165.

12. Esezobor, C. I., Akintan, P., Akinsulie, A., Temiye, E., \& Adeyemo, T. (2016). Wasting and stunting are still prevalent in children with sickle cell anaemia in Lagos, Nigeria. Italian Journal of pediatrics, 42(1), 1-8.

13. Ofakunrin, A. O., Oguche, S., Adekola, K., Okpe, E. S., Afolaranmi, T. O., Diaku-Akinwumi, I. N., ... \& Sagay, A. S. (2020). Effectiveness and safety of hydroxyurea in the treatment of sickle cell anaemia children in Jos, North Central Nigeria. Journal of tropical pediatrics, 66(3), 290-298.

14. Thompson Jr, R. J., Gil, K. M., Burbach, D. J., Keith, B. R., \& Kinney, T. R. (1993). Psychological adjustment of mothers of children and adolescents with sickle cell disease: The role of stress, coping methods, and family functioning. Journal of Pediatric Psychology, 18(5), 549-559.

15. Goodman, A., \& Goodman, R. (2009). Strengths and difficulties questionnaire as a dimensional measure of child mental health. Journal of the American Academy of Child \& Adolescent Psychiatry, 48(4), 400-403.

16. Barbarin, O. A., Whitten, C. F., \& Bonds, S. M. (1994). Estimating rates of psychosocial problems in urban and poor children with sickle cell anemia. Health \& social work, 19(2), 112-119.

17. Thompson Jr, R. J., Gil, K. M., Burbach, D. J., Keith, B. R., \& Kinney, T. R. (1993). Psychological adjustment of mothers of children and adolescents with sickle cell disease: The role of stress, coping methods, and family functioning. Journal of Pediatric Psychology, 18(5), 549-559.

18. Hurtig, A. L., Koepke, D., \& Park, K. B. (1989). Relation between severity of chronic illness and adjustment in children and adolescents with sickle cell disease. Journal of Pediatric Psychology, 14(1), 117-132.

19. Midence, K., Fuggle, P., \& Davies, S. C. (1993). Psychosocial aspects of sickle cell disease (SCD) in childhood and adolescence: a review. British Journal of Clinical Psychology, 32(3), 271-280.

20. Olusanya, O., Okpere, E., \& Ezimokhai, M. (1985). The importance of social class in involuntary 
ferertility control in a developing country. W Africa Medical Journal, 4, 205-212

21. Scoring the Strength and Difficulties Questionnaire for age 4-17+ or 18.20 June 2016. 1-3.

22. SDQ-scoring-instructions for age 14-17 or $18+$. Pages 1-5: https://Terapia.CO.UK/wpcontent/uploads/2020/05/SDQ-scoring-instruction.

23. Hurtig, A. L., \& White, L. S. Children and adolescents: The unexpected terrain of emotional development. SCD: Psychological and psychosocial issues page 20-24. Urbana: University of Illinois Press.
24. Anie, K. A., Egunjobi, F. E., \& Akinyanju, O. O. (2010). Psychosocial impact of sickle cell disorder: perspectives from a Nigerian setting. Globalization and health, 6(1), 1-6.

25. Thompson, R. J., Gil, K. M., Keith, B. R., Gustafson, K. E., George, L. K., \& Kinney, T. R. (1994). Psychological adjustment of children with sickle cell disease: Stability and change over a 10month period. Journal of Consulting and Clinical Psychology, 62(4), 856-866.

Cite This Article: Daniel O. Aina, Ishaya I. Abok, Akinyemi O. D. Ofakunrin, Tolulope O. Afolaranmi, Olumide A. Ajayi, Lucius C. Imoh, Abdulazeez Longwap, Ayuba Affi, Olumide Olaniru, Bawa Abubakar, Christian O. Isichei, Edache S. Okpe (2022). Psychosocial Problems in Adolescents with Sickle Cell Anaemia on Hydroxyurea in Jos, North Central Nigeria. East African Scholars Multidiscip Bull, 5(1), 1-8. 